Lentera Pustaka 2 (2): 95-107, 2016

Copyright (O2016, ISSN: 2302-4666 print/ 2540-9638 online

Available Online at: http://ejournal.undip.ac.id/index.php/lpustaka

\title{
MANAJEMEN LAYANAN KEMAS ULANG INFORMASI DIGITAL DI PDII LIPI
}

\author{
Wahid Nashihuddin ${ }^{1 *}$; Tupan ${ }^{2}$ \\ ${ }^{1,2}$ Pusat Dokumentasi dan Informasi Ilmiah - LIPI \\ Gedung A PDII-LIPI, Jl.Jend.Gatot Subroto No.10 Jakarta Selatan 12710 \\ *)Korespondensi:mamaz_wait@yahoo.com
}

\begin{abstract}
[Title: Digital Information Repackaging Service Management in PDII LIPI] In this globalization era, library, documentation, and information user were very dependent on the internet and digital technology applications to get information. As well as users in PDII, who they were often online information booked and ask the clerk to repackage information in a single topic. There are to facilitate and accelerate the use of literature for research activities or agencies collection. In general, this study aims to describe of management process on digital information repackaging in PDII, that as seen from the aspects: (1) the users characteristics of information service; (2) the activities information repackaging; (3) the types of information repackaging product; and 4) the process of information repackaging in PDII. Describing data descriptively, through observation, literature study, and documentation. The conclusions of this study, are: (1) digital information repackaging is provided based on user needed, both digital immigrants and digital natives; (2) functions of information repackaging are scientific information preservation and dissemination; (3) digital information packaging are managed in PDII are full text selected of information packaging on one topic, on e-books and pohon indutri digital format; and (4) activities of digital information repackaging carried out carefully and systematically based on user requests.
\end{abstract}

Keywords: information repackaging; information packaging; digital information; users; PDII-LIPI

\begin{abstract}
Abstrak
Di era globalisasi ini, pengguna jasa perpustakaan, dokumentasi, dan informasi sangat tergantung pada internet dan aplikasi teknologi digital untuk mendapatkan informasi. Begitu juga halnya dengan pengguna jasa di PDII, yang mana mereka lebih sering memesan informasi secara online dan meminta petugas untuk mengemas ulang dalam satu topik informasi. Hal tersebut guna mempermudah dan mempercepat pemanfaatan literatur untuk kegiatan penelitian atau koleksi lembaga. Secara umum, kajian ini bertujuan untuk mendeskripsikan proses pengelolaan produk kemas ulang informasi digital di PDII, yang dilihat dari aspek: (1) karakteristik pengguna jasa informasi; (2) kegiatan kemas ulang informasi; (3) jenis produk kemas ulang informasi; dan 4) proses kemas ulang informasi di PDII. Data kajian ini dijabarkan secara deskriptif, melalui hasil observasi, studi literatur, dan dokumentasi. Kesimpulan kajian ini, yaitu: (1) kemas ulang informasi digital disediakan untuk memenuhi kebutuhan pengguna PDII, baik digital immigrants maupun digital natives; (2); fungsi kegiatan kemas ulang informasi adalah untuk preservasi dan diseminasi informasi ilmiah; (3) kemasan informasi digital yang dikelola PDII adalah paket informasi full text terseleksi dalam satu topik, dalam bentuk e-book dan pohon industri digital; dan (4) kegiatan kemas ulang informasi digital dilakukan secara cermat dan sistematis berdasarkan permintaan pengguna.
\end{abstract}

Kata kunci: kemas ulang informasi; kemasan informasi; informasi digital; pengguna; PDII-LIPI

\section{Pendahuluan}

Perkembangan teknologi informasi dan komunikasi (TIK) yang begitu pesat berdampak pada perubahan perilaku masyarakat. Perilaku tersebut terlihat pada kecenderungan masyarakat tergantung pada TIK dan jaringan internet dalam memenuhi kebutuhan hidup sehari-hari. Melalui TIK ini pola hubungan komunikasi antar-individu dan antar-organisasi juga menjadi lebih dekat, tanpa dibatasi oleh ruang dan waktu. Straubhar and Rose (2002) mengatakan masyarakat yang tergantung pada teknologi digital dalam mengakses sumber-sumber informasi dapat disebut sebagai masyakat informasi (information society). Masyarakat informasi ini ditandai dengan intensitas yang tinggi atas pertukaran dan 
penggunaan teknologi komunikasi. Wuryanta (2004) mengatakan bahwa jika informasi telah menjadi kebutuhan pokok masyarakat dapat diungkapkan sebagai "information is the lifeblood that sustainspolitical, social and business decision”. Kassam; Iding; Hogenbirk (2013) mengutip Thomas (2011) mengatakan bahwa di era digital ini, partisipasi masyarakat diwujudkan dalam penggunaan alat digital dan media online, guna memacu kreativitas dan ide-ide baru dalam jalur sosial budaya. Terkait dengan praktek teknologi digital natives perlu ada penelitian lebih lanjut tentang keberagaman teknologi digital yang masih tersembunyi agar pemanfaatannya dapat diketahui oleh pengguna.

Terkait dengan perilaku masyarakat yang cenderung lebih tertarik pada teknologi digital ini, tentunya pustakawan atau pengelola dokumentasi dan informasi dapat mengidentifikasi berbagai kebutuhan mereka dengan menyediakan informasi digital yang selektif dan tepat guna. Identifikasi tersebut misalnya dengan cara mengamati media yang digunakan pengguna untuk memesan informasi (email, media sosial, atau instant messaging); format literatur yang dipesan (cetak atau digital); dan bentuk informasi yang diinginkan (file .pdf atau kemasan informasi). Apabila hal tersebut terjadi, maka lembaga perpustakaan, dokumentasi, dan informasi (pusdokinfo) diharapkan dapat menyiapkan segala perangkat layanan dan mengoptimalkan sumberdaya informasinya untuk memenuhi kebutuhan informasi pengguna. Sebagaimana yang telah dilakukan Pusat Dokumentasi dan Informasi Ilmiah - Lembaga Ilmu Pengetahuan Indonesia (selanjutnya disebut PDII) yakni dengan menerapkan layanan online dan kemasan informasi digital. Kajian ini fokus membahas manajemen atau pengelolaan produk-produk kemas ulang informasi (information repackaging) digital PDII dalam rangka pemenuhan informasi pengguna di era digital. Hal tersebut dijelaskan melalui empat bahasan, yaitu tentang: (1) karakteristik pengguna jasa informasi; (2) kegiatan kemas ulang informasi; (3) jenis produk kemas ulang informasi; dan (4) proses kemas ulang informasi di PDII.

\section{Metode Penelitian}

Kajian ini bersifat deskriptif. Data diperoleh melalui observasi, studi literatur, dan dokumentasi. Observasi dilakukan dengan cara mengamati karakteristik pengguna dan berdiskusi dengan pengguna yang memesan produk kemas ulang informasi, baik yang datang langsung ke PDII maupun online. Studi literatur digunakan untuk referensi penulis terkait dengan praktik pengelolaan dan proses kemas ulang informasi. Dokumentasi dilakukan dengan cara meng-capture proses pembuatan kemasan informasi digital. Data yang terkumpul kemudian dianalisis dan diinterpretasikan dalam hasil dan pembahasan kajian. Hasil interpretasi ini kemudian menjadi dasar kesimpulan kajian.

\section{Hasil dan Pembahasan}

\subsection{Karakteristik Pengguna Jasa Informasi PDII}

Melayani pengguna digital berarti ada aktivitas menciptakan atau membuat native digital content, yaitu mengelola dan menciptakan konten digital "original", bukan dalam bentuk analog fisik, seperti menciptakan video digital, audio rekaman, atau "seni digital" artefak. Dokumen digital "original" ini bermakna bahwa objek digital asli dalam kondisi sempurna, baik berupa objek hasil penelitian maupun 
koleksi display. Konten digital asli ini berfungsi sebagai penjaga kualitas dan keteraksesan informasi digital di masa depan (eCulture. 2009). Prensky (2001) mengatakan maraknya permintaan konten digital di era ini karena sebagian besar masyarakat sudah masuk generasi digital, yang memiliki karakteristik: (1) keinginan yang serba cepat dan tidak mentolerir sesuatu yang lambat; (2) keinginan untuk menjadi multitasking; (3) preferensi dalam wujud gambar daripada teks; (4) kecenderungan untuk memproses informasi secara non-linear; (5) preferensi untuk berkolaborasi dan berkoneksi secara konstan dengan rekan-rekan; (6) preferensi untuk belajar melalui kegiatan daripada membaca atau mendengarkan; (7) kecenderungan untuk bekerja sambil bermain ketika di waktu luang; (8) berharap mendapatkan umpan balik dan hadiah atas usaha yang telah dilakukan, seperti yang berlaku dalam permainan; (9) preferensi dalam konteks fantasi, seperti dalam permainan dan tayangan televisi; dan (10) menganggap teknologi sebagai representasi untuk mengatasi kesulitan.

Pendapat Prensky (2001) tersebut menjadi dasar penerapan layanan online dan kemasan informasi digital di PDII. Melalui layanan tersebut diharapkan akan mempercepat dan mempermudah pengguna dalam memanfaatkan informasi yang tepat guna dan informatif. Melalui layanan online, pengguna lebih cepat dalam mendapatkan informasi tanpa harus datang ke PDII (menghemat biaya). Sedangkan dengan memanfaatkan produk kemasan informasi, pengguna dapat menemukan informasi yang spesifik sesuai dengan topik/subjek literatur yang dipesan karena pada hakekatnya informasi yang tercantum dalam kemasan informasi ini adalah informasi yang siap pakai dan mudah digunakan. Hal tersebut tentunya akan mempercepat pemilihan referensi untuk bahan karya tulis ilmiah/penelitian atau memperkaya koleksi perpustakaan (jika produk kemas ulang informasi ini akan di-display untuk koleksi perpustakaan).

Mengacu pada pendapat Prensky (2001) di atas dan melihat cara pengguna PDII dalam memesan dan memanfaatkan informasi digital maka dapat dikatakan bahwa pengguna jasa PDII sudah melek teknologi, dan masyarakat yang telah cenderung tergantung pada teknologi komunikasi digital dapat disebut sebagai digital immigrants atau digital natives. Digital natives merupakan generasi yang lahir pada era digital. Sedangkan digital immigrants, yaitu generasi yang lahir sebelum era digital tetapi kemudian tertarik untuk menggunakan teknologi digital, kemudian mengadopsi hal baru dari teknologi tersebut. Mardina (2011) menambahkan bahwa digital natives merupakan generasi yang lahir pada era digital, dengan ciri multitasking, selalu berjejaring, akses secara random, preferensi pada informasi berupa multimedia interaktif. Generasi digital natives lebih banyak mengisi kehidupan dengan penggunaan komputer, video games, digital music players, video cams, cell phone, dan berbagai macam perangkat permainan yang diproduksi di era digital. Sementara itu, pengguna digital immigrants masuk dalam kelompok masyarakat yang baru mulai belajar hidup digital dan memanfaatkan teknologi digital sebagai gaya hidup. Ketika sudah mengenal teknologi digital internet, mereka sangat menikmati bermain media sosial, seperti Facebook, Twitter, Youtube, dan media online lainnya sebagai tanda bahwa mereka eksis dalam dunia maya.

Dalam konteks pengguna jasa PDII, digital immigrants adalah mereka yang menggunakan jasa kemasan informasi dengan cara datang langsung ke PDII untuk memesan atau melihat produk-produk 
kemasan informasi. Pengguna yang masuk kategori digital immigrants PDII adalah mereka yang berprofesi sebagai dosen, peneliti, dan karyawan/industri yang sudah berusia di atas 40 tahun dan belum pernah mengetahui wujud dan substansi produk kemas ulang informasi. Sementara pengguna digital natives adalah mereka yang memesan informasi ke PDII secara online via-email atau instant messaging. Sebagian besar pengguna digital natives PDII adalah mahasiswa, pustakawan, dosen, peneliti, dan pihak lain yang berusia di bawah 40 tahun yang sudah mengetahui dan pernah memanfaatkan produk kemas ulang informasi, baik melalui website lembaga, media sosial (facebook/Twitter), maupun pameran. Selain dilihat dari cara mendapatkan informasi dan usia pengguna, ada beberapa karakteristik yang lebih spesifik terhadap pengguna jasa informasi PDII yang sebagaimana dijelaskan pada Tabel 1.

Tabel 1. Karakteristik Pengguna Jasa Informasi PDII

\begin{tabular}{|c|c|c|}
\hline & Digital Immigrants & Digital Natives \\
\hline $\begin{array}{l}\text { 1) } \\
\text { 2) } \\
\text { 3) } \\
\text { 4) } \\
\text { 5) }\end{array}$ & $\begin{array}{l}\text { Pemesan masih gagap teknologi } \\
\text { (komputer/internet); } \\
\text { Topik informasi/literatur bersifat } \\
\text { umum/luas dari berbagai jenis koleksi } \\
\text { Datang ke PDII setelah mengirim surat } \\
\text { via-pos atau facsimile; } \\
\text { Memesan artikel digital full text dalam } \\
\text { format .pdf; } \\
\text { Meminta unit perpanjangan layanan PDII } \\
\text { di daerah untuk akses kemasan informasi. }\end{array}$ & $\begin{array}{l}\text { 1) Pemesan sudah melek teknologi } \\
\text { (komputer/internet); } \\
\text { 2) Topik informasi/literatur bersifat spesifik dan } \\
\text { bersumber dari hasil kajian/penelitian; } \\
\text { 3) Datang langsung ke PDII setelah memesan via- } \\
\text { email atau mengisi form penelusuran informasi } \\
\text { online; } \\
\text { Memesan artikel digital dalam bentuk interaktif } \\
\text { (audio-visual/grafis); } \\
\text { 5) Meminta bimbingan teknis penelusuran } \\
\text { informasi dan pembuatan paket kemasan } \\
\text { informasi digital untuk pengembangan layanan } \\
\text { pusdokinfo di institusinya. }\end{array}$ \\
\hline
\end{tabular}

Sumber: Data Observasi Petugas Kemasan Informasi PDII Tahun 2016

\subsection{Kegiatan Kemas Ulang Informasi di PDII}

Iwhiwhu (2008) mengatakan bahwa kegiatan pengemasan informasi menjadi tantangan bagi perpustakaan. Pengemasan (packaging) suatu produk merupakan langkah pertama dalam pemasaran (marketing) yang disesuaikan dengan segmentasi pasar atau kebutuhan pelanggan sehingga memberikan keuntungan secara ekonomi (Tassel and Lisa, 2010). Di PDII, kemas ulang informasi ini merupakan salah satu layanan informasi ilmiah dalam bentuk pengemasan paket-paket informasi hasil kemas ulang informasi yang dibuat berdasarkan isu-isu yang berkembang di masyarakat atau permintaan pengguna. Melalui kegiatan kemas ulang ini diharapkan informasi yang didalamnya lebih mudah dipahami, diserap, dan dapat diadopsi oleh pengguna. Kegiatan kemas ulang informasi ini dimulai dari kegiatan penelusuran, sintesa, analisis, hingga pengemasan informasi dalam bentuk yang menarik dan praktis.

Pengelolaan kemas ulang informasi ini dilakukan oleh Bidang Diseminasi Informasi, mulai dari menganalisis permintaan informasi, penetapan topik/judul, pengemasan informasi, hingga promosi dan diseminasi informasi ke masyarakat di daerah. Konten kemasan informasi terdiri atas kumpulan bibliografi dan artikel full text yang dikelompokkan dan dianalisis berdasarkan kategori dan kelompok sehingga informasi yang disajikan tersusun secara sistematis dan bersifat spesifik. Pengguna dapat memesan kemasan informasi sesuai kebutuhan, baik bentuk cetak atau digital. 
Kemas ulang informasi dilakukan PDII dengan tujuan untuk: (1) menyajikan informasi terseleksi dalam bentuk kemasan tertentu sehingga lebih mudah digunakan dan dipahami oleh pengguna; (2) menyediakan informasi tepat guna karena telah melalui proses mensintesa data dan informasi yang akurat dan mutakhir; (3) menyediakan sarana dan panduan informasi tentang suatu hal; (4) mereview dan mengevaluasi suatu informasi/literatur dari berbagai aspek (jika digunakan sebagai bahan referensi kajian/penelitian). Pernyataan serupa dikatakan Fatmawati (2009) bahwa tujuan kemas ulang informasi untuk: (a) memudahkan memperoleh informasi; (b) mempercepat penelusuran dan penemuan kembaliinformasi; (c) mengevaluasi dan memberikan penafsiran seberapa jauh tingkat pemanfaatannya; (d) memberikan kepuasan kepada pengguna; (e) menghemat ruang dan rak penyimpanan koleksitercetak; (f) memudahkan penelusuran informasi; dan (g) mudah dibawa, ditransfer, dan di-sharingdalam jejaring perpustakaan lain dan transfer pengetahuan/pengalaman antar-pustakawan.

Apabila dilihat dari fungsinya, Dongardive (2013) menjelaskan bahwa kemas ulang informasi berfungsi sebagai: (1) alat untuk menyimpan informasi; (2) penyortir sistematis dan selektifinformasi yang berguna; (3) sarana untuk lebih transmisi informasi yang luas dan pengiriman; (4) alat terjemahan; (5) peluang untuk menyimpan hasil penelitian secara praktis; dan (6) sarana transfer promosi hasil publikasi yang relevan. Mengacu pendapat Dongardive (2013) tersebut, kemas ulang informasi di PDII berfungsi sebagai preservasi dan diseminasi informasi ilmiah. Fungsi preservasi-untuk pelestarian dan akses informasi jangka panjang. Fungsi diseminasi-untuk penyebarluasan informasi tepat guna ke masyarakat/stakeholder yang berada di daerah.

\subsection{Jenis Produk Kemas Ulang Informasi PDII}

Dongardive (2013) menyebutkan ada beberapa jenis kemasan informasi, yaitu current awareness services, selective dissemination of information, analisis dan konsolidasi informasi, abstrak, dokumen terjemahan, direktori, dan newsletters. Mengacu hal tersebut, jenis-jenis produk kemas ulang informasi PDII sebagai berikut (Tabel 2).

Tabel 2. Deskripsi Jenis Produk Kemasan Ulang Informasi PDII

\begin{tabular}{|c|c|c|c|}
\hline No & Jenis kemasan & Paket Kemasan Informasi & $\begin{array}{c}\text { Pengguna Jasa } \\
\end{array}$ \\
\hline 1 & $\begin{array}{l}\text { Penyebaran Informasi } \\
\text { Terseleksi }\end{array}$ & $\begin{array}{ll}\text { - } & \text { Fokus Informasi Indonesia } \\
\text { (sesuai bidang) } \\
\text { - } & \text { Info Ristek } \\
\text { - } & \text { Info HaKI } \\
\text { - } & \text { Tinjauan literatur } \\
\end{array}$ & \multirow[t]{2}{*}{$\begin{array}{l}\text { Peneliti\&Dosen; Pustakawan } \\
\text { (database suatu bidang); } \\
\text { mahasiswa (tinjauan } \\
\text { literatur) }\end{array}$} \\
\hline 2 & $\begin{array}{l}\text { Current Awarnness } \\
\text { Services/Kesiagaan } \\
\text { Informasi }\end{array}$ & $\begin{array}{ll}\text { - } & \text { Informasi Kilat } \\
\text { - } & \text { Buletin Info Kilat } \\
\text { - } & \text { Kumpulan Abstrak } \\
\text { - } & \text { Database suatu bidang } \\
\end{array}$ & \\
\hline 3 & Ringkasan Eksekutif & $\begin{array}{ll}\text { - } & \text { Info Ristek } \\
\text { - } & \text { Ringkasan Eksekutif }\end{array}$ & Pengambil Kebijakan \\
\hline 4 & Brosur/Pamflet & $\begin{array}{ll}\text { - } & \text { Pohon Industri } \\
\text { - } & \text { Panduan Usaha } \\
\text { - } & \text { Info TTG } \\
\text { - } & \text { Kliping } \\
\end{array}$ & $\begin{array}{l}\text { Industri kecil - } \\
\text { Menengah/UKM; Mahasiswa } \\
\text { (Kliping) }\end{array}$ \\
\hline 5 & Proposal pabrik & Studi kelayakan pabrik & Industri besar \\
\hline
\end{tabular}


Jenis-jenis produk hasil kemas ulang informasi di atas dijelaskan sebagai berikut.

1) Fokus Informasi Indonesia sesuai bidang_disajikan bagi para ilmuwan, peneliti, dosen, dan masyarakat yang berkepentingan untuk mengikuti perkembangan informasi iptek Indonesia secara berkesinambungan. Publikasi ini dalam bentuk kumpulan abstrak dari majalah ilmiah indonesia yang diterbitkan setiap 2 bulan, terdiri dari bidang farmasi, biologi, kesehatan, kimia, komputer, lingkungan hidup, politik, ekonomi, pendidikan, hukum, manajemen, perpustakaan, teknologi pangan dan rekayasa.

2) Info Ristek-memuat informasi mengenai topik/permaalahan yang perlu mendapat perhatian untuk membantu penentu kebijakan mencari solusinya.

3) Info HaKI—informasi ini dimaksudkan untuk mensosialisasikan masalah HaKI di kalangan para peneliti, industriawan, dan praktisi hukum agar dapat mengikuti dan mengetahui hal yang berkaitan dengan Hak atas Kekayaan Intelektual, seperti hak paten, hak cipta, dan hak merk. Info HaKI disajikan dalam bentuk artikel yang diterbitkan setiap 3 bulan sekali.

4) Paket Informasi Teknologi (PITI) — merupakan kumpulan informasi ilmiah mengenai tinjauan perkembangan teknologi suatu bidang tertentu. Memuat informasi terseleksi mengenai ide-ide baru untuk dikembangkan, yang bersumber dari buku, laporan penelitian, majalah, paten, hasil seminar, dan standar. PDII telah berhasil memenuhi pesanan PITI dari berbagai kalangan industri dan peneliti sejak tahun 1987.

5) Informasi Kilat - pelanggan informasi kilat akan memperoleh fotokopi daftar isi majalah ilmiah luar negeri, baik yang dilanggan PDII maupun yang ada di luar negeri sesuai dengan frekuensi terbit dari majalah yang dipilih.

6) Buletin Abstrak-pelanggan buletin abstrak akan memperoleh abstrak artikel dari majalah ilmiah luar negeri yang dipilih sesuai dengan frekuensi terbit majalah yang dipilih.

7) Kumpulan Abstrak — setiap bulan pelanggan akan memperoleh informasi terbaru berupa abstrak dari berbagai majalah ilmiah luar negeri sesuai topik yang diminati.

8) Database suatu bidang - memuat kumpulan bibliografi dan abstrak hasil penulusuran literatur dari beberapa topik dalam satu bidang. Sumber informasi yang digunakan, antara lain: Koleksi Perpustakaan PDII-LIPI, CD-ROM, Internet, Chemical Abstrack, dan informasi lainnya. Karena dalam bentuk database maka konten informasi yang terkandung di dalamnya dapat ditelusur dengan mudah melalui indeks pengarang, kata kunci, dan sebagainya.

9) Pohon Industri-disusun dengan tujuan memberikan gambaran jenis-jenis produk yang dapat dibuat dari suatu komoditi. Komoditi tersebut berupa bahan baku dari hewan, tumbuhan, atau material lain yang dianalisis berdasarkan aspek kemanfaatan dan nilai ekonomisnya. Konten informasi paket kemasan pohon industri, terdiri atas bagan atau diagram alir yang menghubungkan bahan komoditi utama (yang dianalisis) dengan uraian penjelasan yang terkait dengan manfaat dari setiap bagian komoditi yang dianalisis. Setiap manfaat dari bagian komoditi kemudian disertakan artikel full text-nya yang dapat dijadikan referensi dalam 
kegiatan pengelolaan bahan komoditi tersebut. Diharapkan dari informasi yang dibuat dapat merangsang pengusaha untuk melakukan dan mengembangkan diversifikasi produk yang bernilai ekonomi.

10) Panduan Usaha—merupakan petunjuk praktis untuk mengembangkan atau mendirikan suatu usahadalam skala rumah tangga, Industri kecil dan menengah. Melalui informasi ini diharapkan masyarakat dapat mencoba melakukannya sendiri. Informasi yang dicakup meliputi bahan baku, peralatan, biaya, dan informasi lain yang terkait.

11) Paket Penawaran teknologi—untuk memberikan wawasan bagi usaha kecil maupun menengah dan Pemeritah Kabupaten/Kota dalam mengembangkan produk melalui teknologi yang telah dikembangkan oleh lembaga penelitian di Indonesia. Disajikan dalam bentuk informasi yang mencakup tingkat pengembangan produk, uraian singkat, keuntungan ekonomis dan teknologi.

12) Seri Info TTG-berisi daftar tulisan mengenai teknologi sederhana dalam berbagai bidang usaha masyarakat yang dikumpulkan dari majalah, buku, kliping koran, standar, dan paten.

13) Pangkalan data Teknologi Tepat Guna—merupakan database informasi ilmiah (hasil litbang) yang ditujukan bagi masyarakat yang ingin mengembangkan usaha dan diversifikasi produk, seperti pangan.

Pada tahun 2016, Bidang Diseminasi Informasi telah menetapkan 9 judul utama kemasan informasi digital dalam bentuk paket informasi tepat guna terseleksi dan pohon industri digital. Berikut ini 9 judul kemasan informasi digital PDII tahun 2016: (1) Pohon Industri Tebu; (2) Pohon Industri Udang; (3) Pohon Industri Kopi; (4) Paket Informasi Terseleksi bidang Lingkungan, Seri: Pemanasan Global; (5) Paket Informasi Terseleksi bidang Kesehatan, Seri: Diabetes; (6) Paket Informasi Terseleksi bidang Energi, Seri: Biodiesel; (7) Paket Informasi Terseleksi bidang Industri, Seri: Minyak Atsiri; (8) Paket Informasi Terseleksi Bidang Energi, Seri Energi Matahari; dan (6) Policy Brief bidang pangan. Selain informasi kemasan tersebut, juga membuat kemasan informasi digital (e-book) berbasis potensi daerah, dengan judul: (1) Kemasan Informasi untuk Daerah (Bengkulu); (2) Kemasan Informasi untuk Daerah (Bulukumba); (3) Kemasan Informasi untuk Daerah (Lingga); (4) Kemasan Informasi untuk Daerah (Probolinggo); (5) Kemasan Informasi untuk Daerah (Tanjung Pinang); (6) Kemasan Informasi untuk Daerah (Batam); (7) Kemasan Informasi untuk Daerah (Banten); (8) Kemasan Informasi untuk Daerah (Belitung); dan (9) Kemasan Informasi untuk Daerah (Kebumen). Seluruh paket kemasan informasi digital di atas tersedia hingga konten full text-nya. Sementara itu, jenis kemasan informasi PDII yang (Tabel 2) kurang diminati oleh pengguna karena hanya berisi daftar bibliografi. Gambar 1 - Gambar 3 merupakan contoh tampilan konten kemasan informasi digital PDII tahun 2016. 


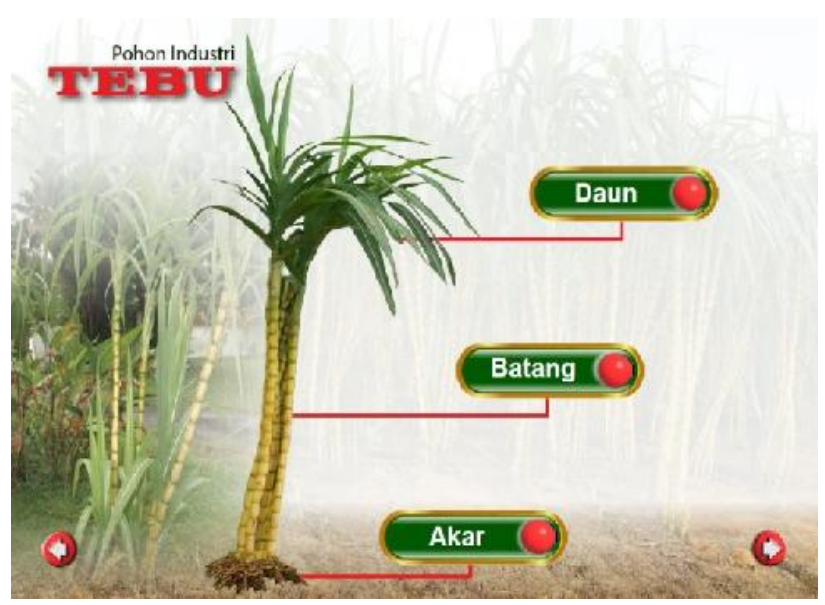

Gambar 1. Pohon Industri Digital "Tebu"

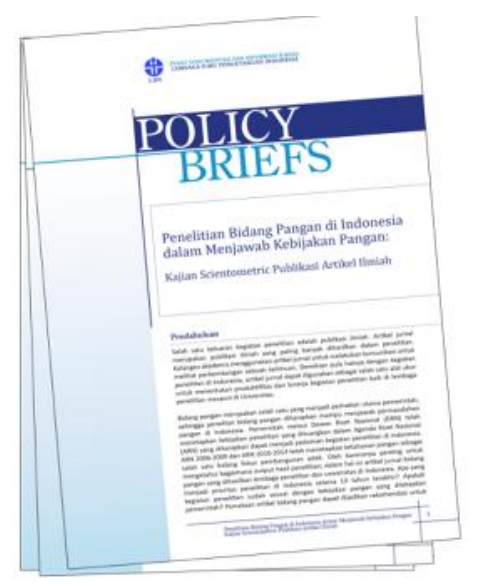

Gambar 2. Paket Informasi "Policy Brief"
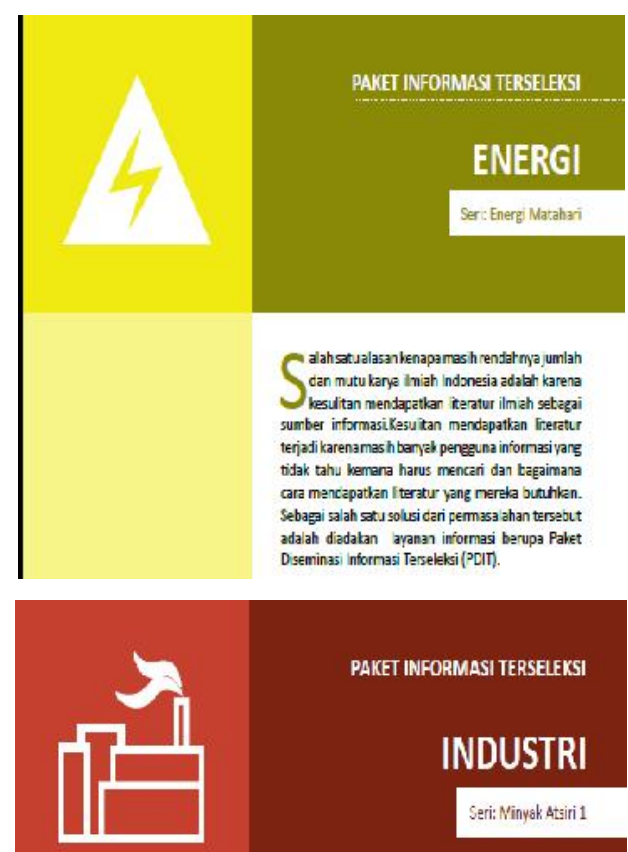

Seri: Ninygk Attiri 1

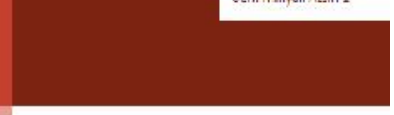

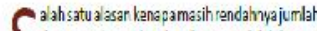
dan rusu kaya in ah Indonesia adalah kara?

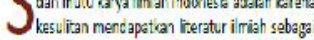
surber inforrasi.Kesulitan mendapatkan literatur. terjacikerera masi h barnyak sengguna informasiyang tidak tahu kemana harus menceri dan tagaimana

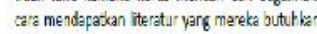
Setagai salah satu solusi dari ferm assalkhan tersejut adakh ciadakan kapanan inicmasi terupa Faket Diseminasi Ifformasi Terseleksi |PCT)!

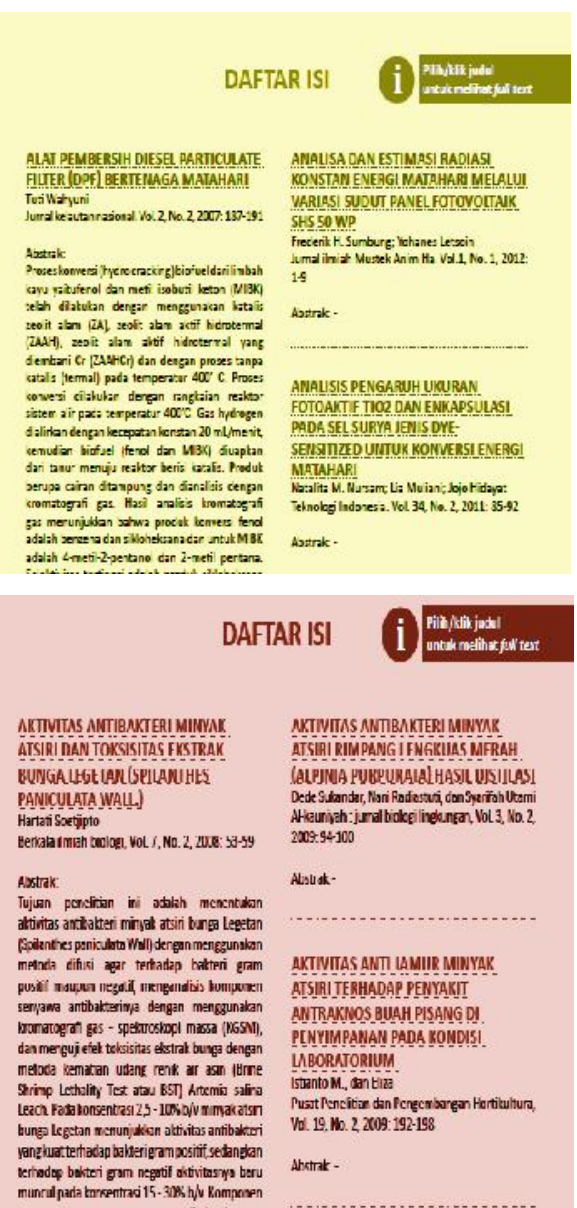

Gambar 3. Paket Informasi Terseleksi "Energi" dan "Industri”"

Gambar 4 - Gambar 5 merupakan contoh tampilan paket kemasan informasi digital PDII bentuk CD/DVD tahun 2016. 

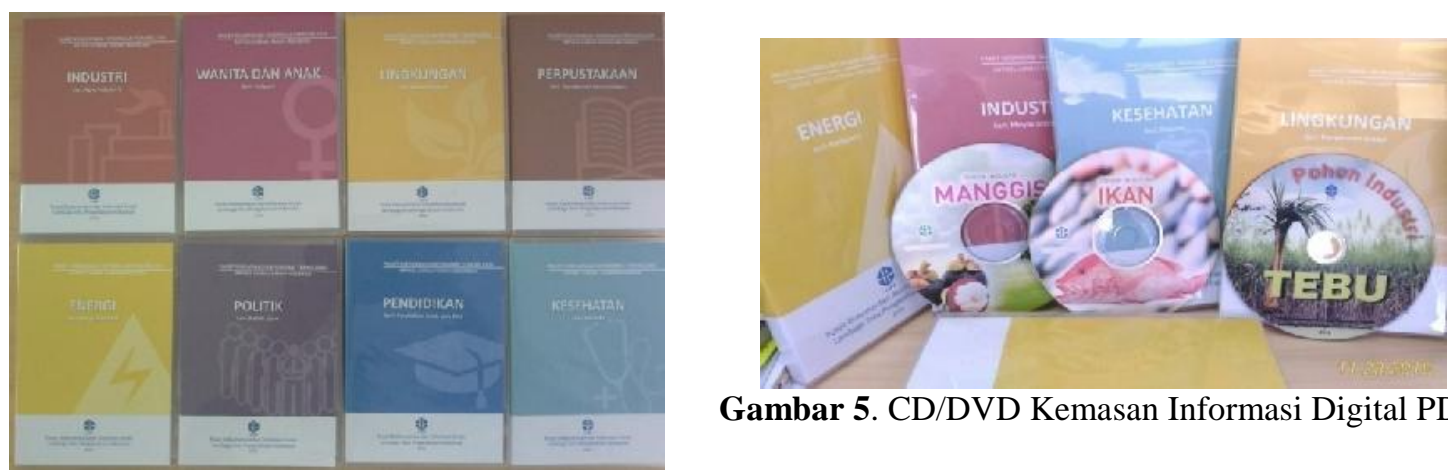

Gambar 5. CD/DVD Kemasan Informasi Digital PDII

Gambar 4. Box CD/DVD Kemasan Informasi Digital PDII

Secara umum, jenis-jenis produk kemas ulang informasi di atas dapat dipesan sesuai kebutuhan pengguna. Setiap informasi yang tercantum di dalamnya mengandung informasi mutakhir yang memiliki manfaat tepat guna; serta untuk merangsang pembaca/pengguna kemasan agar lebih inovatif dalam pemberdayaan ekonomi dan kehidupan yang lebih baik sesuai dengan kapasitas dan kompetensinya masing-masing.

\subsection{Proses Kemas Ulang Informasi PDII}

Bagi pengguna atau masyarakat yang ingin memesan kemasan informasi digital PDII, baik individu maupun kolektif (institusional), dapat melalui email, datang langsung ke PDII, dan/atau kerjasama (kemitraan). Bagi pengguna yang memesan kemasan informasi melalui email dapat menghubungi petugas penelusuran (di email: penelusuran@mail.lipi.go.id) atau layanan publik PDII (di email: layanan.pdii@mail.lipi.go.id). Bagi pemesan yang datang langsung ke PDII dapat menghubungi Kepala Bidang Diseminasi Informasi atau petugas penelusuran informasi. Bagi pengguna yang ingin menjalin kerjasama dalam hal pembuatan kemasan informasi dapat menghubungi langsung Bagian Umum PDII, Kepala Bidang Diseminasi Informasi, atau Kepala PDII. Pelaksanaan kerjasama ini ditandai dengan penandatanganan kontrak kerjasama (MoU) oleh kedua belah pihak, yakni PDII dan lembaga mitra. Dalam tahap permohonan pemesanan kemasan informasi ini, pengguna harus: (1) menyebutkan topik atau judul literatur yang menjadi lingkup informasi kemasan secara jelas; (2) menetapkan format kemasan yang dipesan (cetak/digital; biasa (teks/grafis)/audio-visual); dan (3) menyatakan kesanggupan dan kepatuhan administrasi keuangan sesuai kebijakan yang berlaku/sesuai kesepakatan bersama.

Setelah ketiga hal di atas dipenuhi pemohon kemasan, langkah berikutnya adalah koordinasi dan identifikasi kegiatan kemas ulang informasi oleh pimpinan lembaga dan petugas layanan, yang mencakup: (1) tujuan pemesanan kemasan informasi; (2) jenis informasi yang disajikan (berdasarkan topik atau judul yang dipesan); (3) format kemasan informasi yang diinginkan pemesan (cetak/digital); (4) petugas pembuat kemasan; (5) bahan dan sarpras untuk membuat kemasan informasi; (6) alokasi biaya pembuatan kemasan informasi; dan (7) promosi dan diseminasi kemasan informasi.

Setelah identifikasi dilakukan, langkah berikutnya adalah membuat kemasan informasi. Dongardive (2013) menjelaskan proses pembuatan kemas ulang informasi dengan beberapa tahapan, yaitu: (1) 
menyiapkan informasi ringkas dan terseleksi; (2) menganalisis informasi secara singkat sesuai dengan target pengguna, isi informasi, anggaran kemasan, serta siklus hidup dari kemasan informasi yang akan dibuat; (3) menetapkan kriteria desain kemasan informasi agar menarik minat pembaca; (4) merancang kemasan informasi dalam berbagai bentuk ukuran dan variasi; (5) memproduksi kemasan informasi dalam jumlah banyak; dan (6) mengevaluasi pemanfaatan kemasan informasi (ada feedback dari pembaca/pengguna). Mengacu pendapat Dongardive (2013) tersebut, pembuatan kemasan informasi di PDII dilakukan dengan tahapan: (1) menetapkan topik, jenis kemasan, dan pelaksana kegiatan; (2) menelusur literatur sesuai dengan topik dan judul kemasan; (3) menganalisis literatur hasil penelusuran; (4) menyusun (setting) desain dan template kemasan informasi; (5) menggandakan paket kemasan sesuai kebutuhan; dan (6) evaluasi dan pelaporan (Tupan dan Nashihuddin 2015).

Berikut ini contoh tahapan pembuatan kemasan informasi digital "Pohon Industri Tembakau" (hasil kerjasama PDII dengan Balai Penelitian Tembakau milik Pemerintah Daerah Jember tahun 2016) yang mengacu penjelasan di atas.

- Pengumpulan bahan kemasan, meliputi: (a) penelusuran informasi ke berbagai sumber informasi global, baik tercetak maupun elektronik; (b) penyediaan artikel lengkap (full text);

- Mendata dan menyeleksi literatur hasil penelusuran yang relevan, meliputi: (a) menganalisis informasi; (b) memeriksa dan mensintesa hasil penelusuran;

- Menyajikan informasi dalam bentuk pohon industri digital interaktif $\rightarrow$ layout, setting, design, review design, dan aplikasi flash;

- Penggandaan pohon industri digital interaktif dalam bentuk CD sesuai kebutuhan;

- Mengevaluasi kemanfaatan produk kemas ulang informasi.

Adapun dokumentasi proses pembuatan kemasan informasi digital "Pohon Industri Tembakau" sebagai berikut (Gambar 6 - Gambar 11).

1) Halaman utama $\rightarrow$ tampilan komoditi utama tanaman "tembakau" (klik "Mulai"—next content).

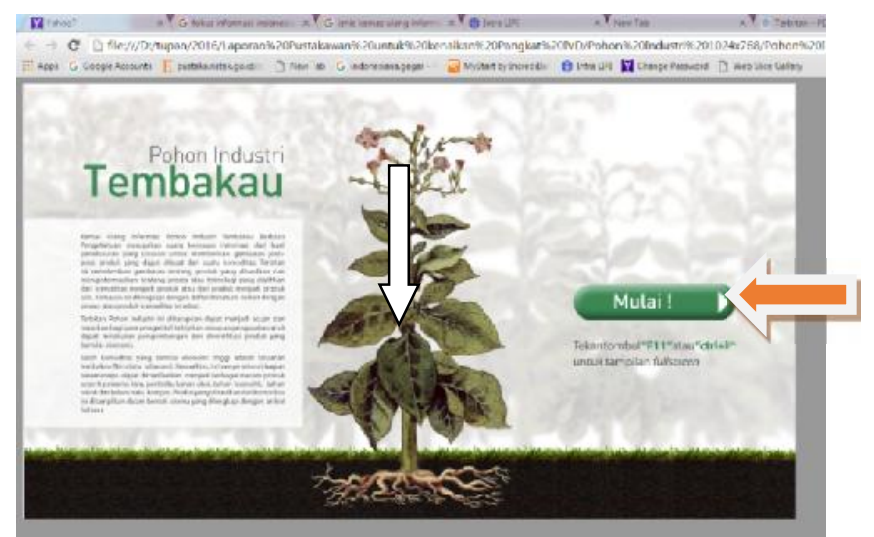

Gambar 6. Halaman utama tampilan pohon industri digital "tembakau" 
2) Halaman kedua $\rightarrow$ tampilan bagian-bagian komoditi tanaman "tembakau", yaitu biji, bunga, daun, batang, dan akar (sebagai contoh klik "Biji”).

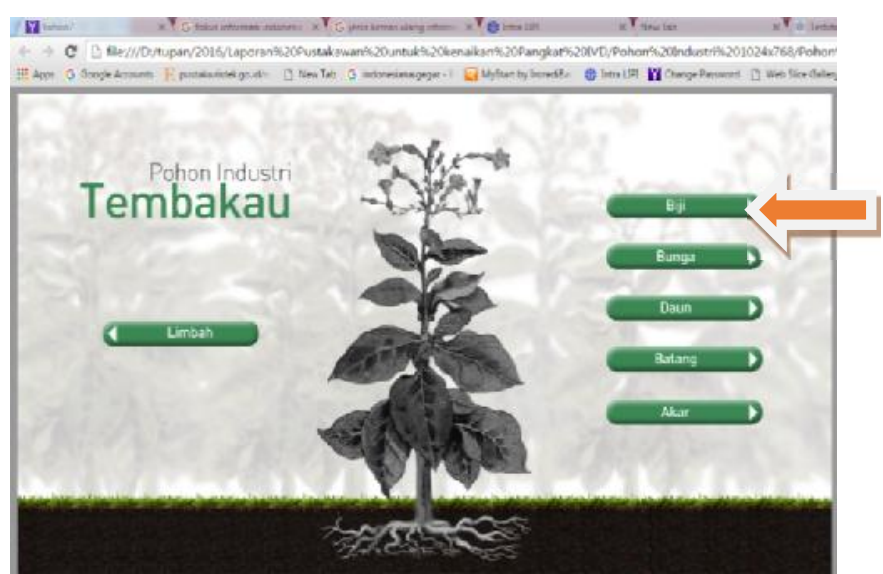

Gambar 7. Halaman kedua tampilan bagian-bagian komoditi tanaman "tembakau”

3) Halaman ketiga dan keempat $\rightarrow$ tampilan bagian "biji tembakau" (kiri) dan hasil ekstraksi biji tembakau menjadi "minyak dan nikotin" (kanan).

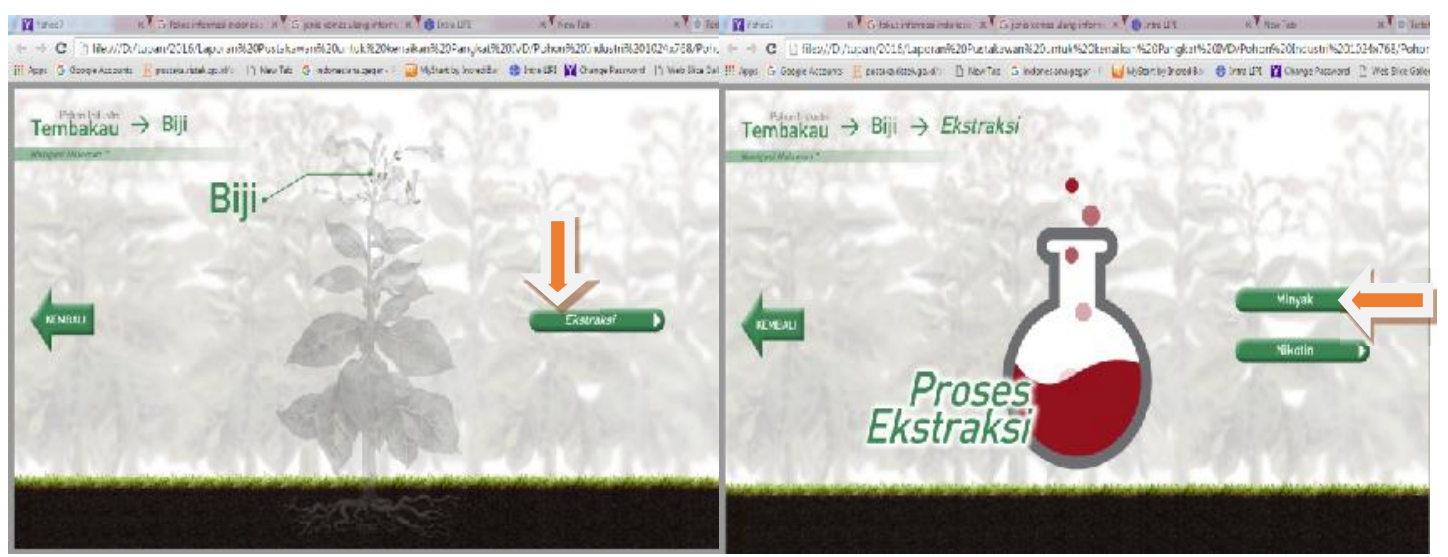

Gambar 8. Halaman ketiga dan keempat tampilan bagian hasil ektraksi "biji tembakau"

4) Halaman kelima $\rightarrow$ tampilan hasil ekstraksi biji tembakau menjadi "minyak" $\rightarrow$ bermanfaat untuk biofuel, sabun, pelarut cata, varnish, dan minyak salad.

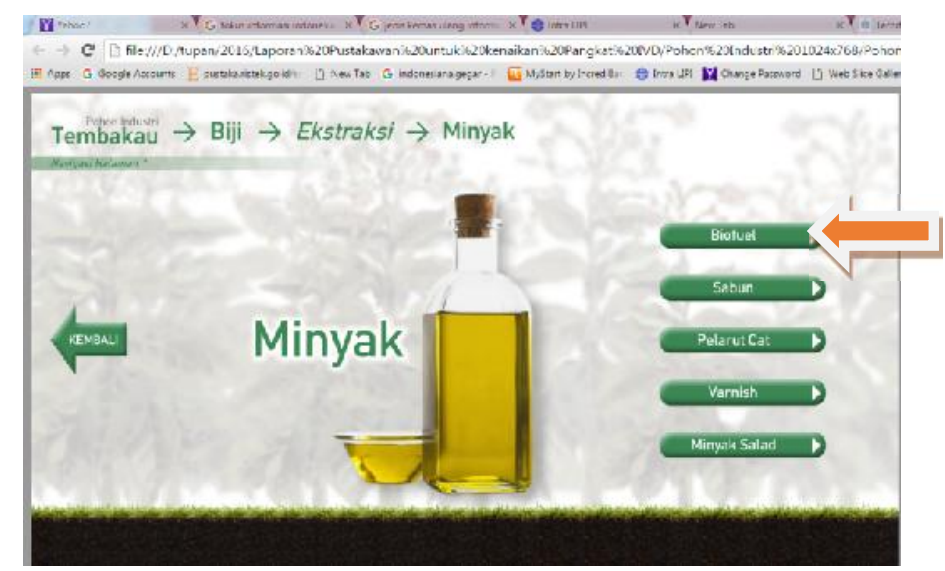

Gambar 9. Halaman kelima tampilan bagian hasil ektraksi "biji tembakau" menjadi "minyak" 
5) Halaman keenam $\rightarrow$ tampilan daftar artikel digital full text yang terkait dengan manfaat minyak biofuel hasil ekstraksi biji tembakau (terdapat enam judul artikel).

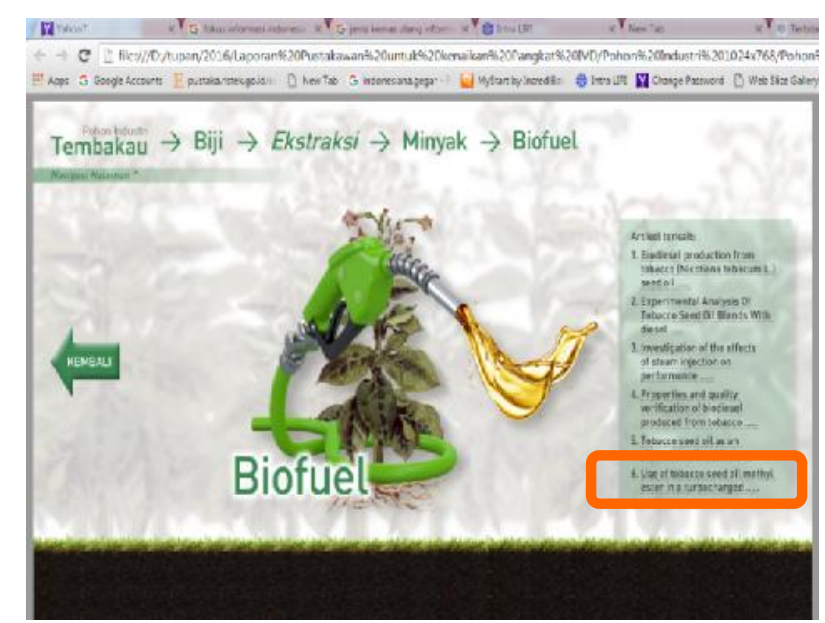

Gambar 10. Halaman Keenam daftar artikel digital full text tentang manfaat minyak biofuel hasil ekstraksi biji tembakau

6) Halaman ketujuh, tampilan artikel digital full text yang membahas tentang manfaat minyak biofuel hasil ekstraksi biji tembakau.

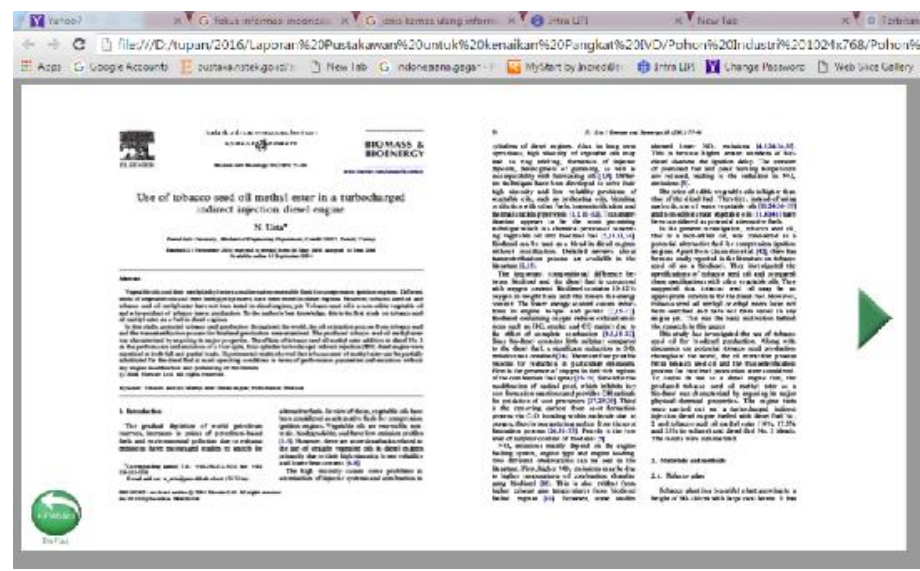

Gambar 11. Tampilan Artikel digital full text tentang manfaat minyak biofuel hasil ekstraksi biji tembakau

Berdasarkan uraian di atas, terlihat bahwa proses pembuatan kemas ulang informasi digital membutuhkan kecermatan yang tinggi dalam menyeleksi dan menganalisis informasi yang relevan dengan topik/judul kemasan. Di samping itu, petugas pembuat kemasan juga harus memiliki kemampuan mengoperasionalkan program aplikasi grafis dan animasi, seperti PhotoShop, InDesign, Adobe Acrobat, Corel Draw, dan sebagainya.

\section{Penutup}

Pada era digital ini, lembaga pusdokinfo perlu berinovasi dalam pengembangan layanan informasinya, termasuk dalam pengelolaan kemasan informasi digital. Hal tersebut dilakukan karena tuntutan peningkatan kualitas layanan lembaga dan mengikuti perilaku pengguna/stakeholder. Sebagian besar pengguna jasa pusdokinfo lebih menyukai informasi yang praktis dan terjangkau dalam bentuk 
digital untuk memenuhi kebutuhan informasinya. Dalam pengemasan informasi, lembaga harus memperhatikan perilaku dan karakteristik pengguna, baik yang digital imigrants maupun digital natives. Prinsipnya bahwa kemasan informasi digital yang dibuat PDII harus mudah digunakan dan sesuai kebutuhan mereka.

\section{Daftar Pustaka}

eCulture. 2009. Native Digital Content. Chapter OnCultural Content in the Digital Age. pp 81-100. DOI 10.1007/978-3-540-75276-9_9 (http://link.springer.com/chapter/ 10.1007/978-3-540-75276-9_9, tanggal 25 Agustus 2016).

Fatmawati, Endang. 2009. Kemas Ulang Informasi: Suatu Tantangan Bagi Pustakawan. MajalahMedia Pustakawan, Vol.16, No.1 dan 2 Agustus.

Iwhiwhu, Enemute Basil. 2008. "Information Repackaging and Library Services: A Challenge to Information Professionals in Nigeria". Journal Of Library Philosophy And Practice, Paper 178. (http://digitalcommons.unl.edu/cgi/viewcontent.cgi?article=1181 \&context=libphilprac, tanggal 23 Agustus2016).

Kassam, Alnaaz; Marie Iding; Pieter Hogenbirk. 2013. Unraveling the Digital Divide: Time Well Spent Or "Wasted"?.Educ Inf Technol, 18:215-221, DOI 10.1007/s10639-012-9233-9.

Mardina, Riana. 2011. Potensi Digital Natives dalam Representasi Literasi Informasi Multimedia Berbasis Web di Perguruan Tinggi. Jurnal Pustakawan Indonesia, Vol.11, No.1.

Prensky, Mark. 2001. Digital Game-Based Learning. New York: McGraw-Hill.

Prensky, Mark. 2001. Digital Natives, Digital Immigrant. On the Horizon--MCB University Press, Vol.9 (5).

Straubhaar, Joseph and Robert La Rose. 2002. Media Now: Communication Media in the Information Age. Australia: Wadsworth.

Hartinah, Sri. 2005. Kemas Ulang Informasi. Disampaikan pada Pelatihan Pengenalan Kemas Ulang Informasi pada UPT BIT - Bandung 27-28 Juli.

Tassel, Joan Van and Lisa Poe-Howfield. 2010. "Packaging, Repackaging, and Marketing ContentChapter 9”. Published By Elsevier Inc. DOI: 10.1016/B978-0-240-81020-1.00009-9.

Tupan dan Wahid Nashihuddin. 2015. Kemas Ulang Informasi untuk Pemenuhan Kebutuhan Informasi Usaha Kecil Menengah: Tinjauan Analisis di PDII-LIPI. BACA: Jurnal Dokumentasi dan Informasi, 36 (2) Desember: 109-124.

Wuryanta, AG. Eka Wenats. 2004. Digitalisasi Masyarakat: Menilik Kekuatan dan Kelemahan Dinamika Era Informasi Digitaldan Masyarakat Informasi. Jurnal Ilmu Komunikasi, Vol.1, No.2, Desember: 131-142. 